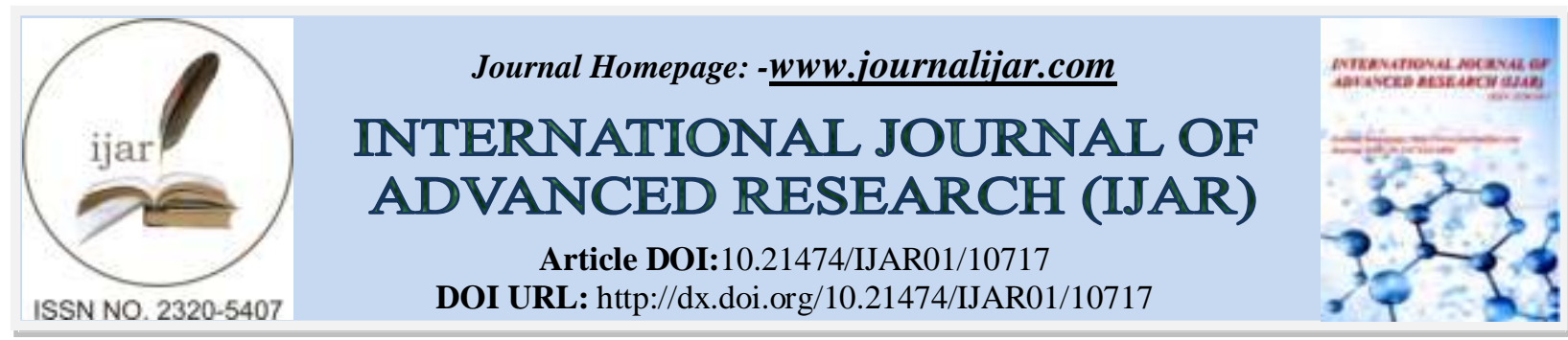

RESEARCH ARTICLE

\title{
POLITICAL ADVERTISING AND VOTERS' BEHAVIOUR IN LOKOJA DURING 2019 GOVERNORSHIP POLL IN KOGI STATE, NIGERIA
}

\author{
Ata-Awaji Anthony Reuben ${ }^{1}$ and Zekeri Momoh ${ }^{2}$ \\ 1. Lecturer, Department of Mass Communication, Salem University, Lokoja, Kogi State-Nigeria. \\ 2. Lecturer, Department of Public Administration, Salem University, Lokoja, Kogi State-Nigeria.
}

\section{Manuscript Info}

..........................

Manuscript History

Received: 22 January 2020

Final Accepted: 25 February 2020

Published: March 2020

Keywords:-

Governorship Poll, Political Advertising,

Voters' Behaviour, Election, Lokoja

\section{Abstract}

Politics, being a big business comes with buzz and many days of struggle to be known; to be more exposed to the electorate and be able to gain goodwill. It also comes with a lot of interests and attracts many people who struggle to form a government. In Kogi State, as a prelude to the 2019 governorship election that took place in the state, political advertising was launched. This study is, therefore, about political advertising and voters' behaviour in Lokoja during the 2019 governorship poll. Survey method was adopted in generating primary data for the study. Consequently, a quantitative approach was adopted in analyzing the data extracted from 384 samples, out of the 400 samples size that was chosen based on Taro Yamane's formula. Stratified random sampling was adopted in the distribution of copies of the questionnaire. Among other findings, the study unravelled that political advertising on and in the various mass media had little effect on voters' behaviour in Lokoja during the 2019 governorship poll. The study also discovered that the electorate got to know more about the candidates through the political advertising but the hype did not rule out their interests and envisaged gains which made them make rational choices. Given this, the researchers recommended among others that politicians should have charismatic dispositions that will position them on the minds of the electorate, and should not depend largely on political advertising for acceptance by the electorate.

CopyRight, IJAR, 2020, All rights reserved.

\section{Introduction:-}

Politics is big business the world over. It comes with buzz and many days of struggle to be known, more exposed to the electorate and be able to gain goodwill. It also comes with a lot of interests and attracts many people who struggle to form a government. The essence of this in an ideal world is to get power, have control over the state's resources and manage them on behalf of the state for the reduction of afflictions of the masses.So, politics is about the struggle between and among persons interested in the acquisition and consolidation of power.It is asombre business which requires determination, leadership and followership. It is about the people from whom the legitimacy of would-be form government comes. A big event, it also involves many strategies, including a campaign to position oneself, selling parties' candidates to the electorate and persuade them to vote a candidate or candidates sponsored by a political party. 
The essence of politics is to ensure that individuals, as well as the society, are guided and guarded, to ensure survival and prevent avoidable conflicts; adjudicate on conflict to ensure peace in the society. It is to ensure orderliness in society and avoid arbitrariness. It is from politics or political atmosphere that government is formed. So, the formation of government is subsumed in politics. Politics goes with political parties. In order words, it has a patternan organized system through which the struggle for the acquisition of power is staged. In Britain, political parties were formed beginning from 1558. Other countries of the world also had their political parties, before 1558 and some thereafter. One of the countries that are credited with the early political system is Greece where the practice of democracy began.

The geographical expression that is now known as Nigeria even before independence had witnessed the buss from politics amid campaigns by various political parties. Historically, elective democracy was introduced in Nigeria in 1919, and by 1920 the first election into Lagos Town Council was conducted. But the first political party in Nigeria was known as Nigerian National Democratic Party, formed in 1923 by Herbert Macaulay.This party was unbeatable in Lagos until 1938. It means that at each election periods of 1923, 1928 and 1933 which it won; it campaigned for votes. Approaches may have flourished but there is no gainsaying that the electorate was wooed by the politicians and their parties. In the aftermath of independence and until now, the situation has not changed. What has changed in the contemporary Nigerian society are the strategies adopted by politicians to get a vote from the electorate. Also, now there is a cornucopia of media of mass information in which political communication takes place, as politicians struggle hard to reach the electorate and convince them for a vote.

Politics in contemporary Nigerian society goes with a lot of political communication. Parties manifestoes are presented to the electorate, opinions of the people manipulated, opponents blackmailed while candidates of a particular party positioned on the minds of the people as the best for the job of the president, governor and senator etc. All these are promoted largely in the media through political advertising which covers the radio, television, newspaper, magazine, billboards, poster and social media.

The period clearly defined by the Nigerian Electoral Guidelines for a political campaign, leading to the Governorship Election in Kogi State which took place on November 16, 2019, was not different. It witnessed campaigns by political parties who bought time on radio, television, and space in the newspaper and social media, to be able to reach a large number of electorate in Kogi State. While the campaigns period lasted, the electorate was appealed to, persuaded and begged to vote candidates, as jingles, interviews and other communication strategies were adopted on and in the media to sell the candidacy of the various people jostling for the position of governor of Kogi State. After the campaigns, elections were conducted and the incumbent governor, Yahaya Bellow was declared by the electoral umpire (the Independent National Electoral Commission, INEC) as the winner of the poll. This is predicated on the fact that he had the highest number of the vote cast. Therefore, it is the thrust of this work to find out if the electorate voted Yahaya Bellow and other candidates because of the acceptance of their candidacies through the political advertising amid campaigns on and in the media or voted them based on other factors.

\section{State of the problem:}

The campaign is at the heart of politics as people struggle to seize power and form government. In Nigeria, this trend can be described as episodic (action-packed). The media are used more by politicians in reaching out to the electorate than other means or modes of communication. This is because media messages reach million or large heterogeneous people simultaneously in different places.

During the campaign period heralding the 2019 Governorship Election in Kogi State, politicians promoted themselves in the mass media and persuaded the electorate to vote them, for the position of governor of the state as they struggled to occupy the Lord Luggard's house; a metaphor for the Kogi State Government House.The various candidates campaigned using the mass media. The various candidates got votes but the incumbent Governor Yahaya Bello got the highest number of vote cast and was declared the winner of the poll. This was against the prediction of many people who envisaged that the PDP candidate Musa Wada would emerge victorious since he is of the Igala ethnic group; a group that has the largest population in the state. Also, there was a widespread accusation against Yahaya Bello that his performance was the worst since the history of the state. Yet he emerged victorious at the poll. Did the electorate change their minds and voted Bello due to the promises he made amid political advertising in the state?The problem of this work is, therefore, preconceived in the foregoing. 


\section{Research objectives:-}

The objective of this work is to find out the relationship between political advertising and voters' behaviour in Lokoja during 2019 Governorship poll in Kogi State, Nigeria. Specifically, the aim of the study revolves around the need to:

1. Ascertain the exposure of electorate in Lokoja to political advertising during the 2019 governorship poll in Kogi State,

2. Determine if political advertising influence their voting behaviour,

3. Find out other factors that sway their voting behaviour.

\section{Research questions:}

1. Did the electorate expose themselves to political advertising during the 2019 governorship election in Kogi State?

2. Did political advertising influence voting behaviour of the electorate in Lokoja during 2019 Governorship election?

3. What factors sway voting behaviour of the electorate in Lokoja during 2019 Governorship election?

\section{Hypothesis:}

There is a significant relationship between political advertising on radio, television, billboards and in the social media and voters' choice ofa candidate during polls.

\section{Theoretical framework:}

This work is supported by two theories: Sociological and Rational Choice Theories. The sociological theory emerged following the work ofLazarsfeld, Berelson, \&Gaudet, entitled "The People's Choice", published in 1944. It was about the U.S. presidential election at the time. The theory holds that the behaviour of the electorate is tied to their sociological constructs. That is the groups, class, age grade and association etcetera. It maintains that voters or electorate remain rooted in the group's interest and reflections, rather than having feelings for a political party due to family influence. The theory, while stressing that the media have a limited effect on the voting decision, noted that social group and personality of the individual voters determine their voting behaviour. As noted by Heywood (2007), the theory links voting behaviour to group membership, suggesting that electors tend to adopt a voting pattern that reflects the economic and social position of the group to which they belong. Rather than developing a psychological attachment to a party based on family influence, this model highlights the importance of social alignment, reflecting the various divisions and tensions within society. The most significant of these divisions are class, gender, ethnicity, religion and region (p.267).

\section{Theory of rational choice:}

The rational choice theory is also known as Economic Theory of Democracy is attributedtoAnthony Downs, the following is work entitled "An economic theory of Democracy.", published in 1957.According to Rui (2010),the operation of the model is based on three fundamental premises: (1) all decisions - those that are made by voters and political parties - are rational, i.e., guided by self-interest and enforced by the principle of maximization of action's utility; (2) the democratic political system implies a level of consistency that supports predictions about the consequences of decisions made by voters and political parties, i.e., their agents - voters, parties and government - are responsible and trustworthy, which makes it possible to make predictions aboutthe consequences that result from different choices, and (3) the democratic system assumes - despite the consistency stated in the previous point - a level of uncertainty, sufficiently important to allow different options (p.158). From the above submissions, it means that the theory holds that voters' behaviour and decision are based on interest and the utility (benefits) to derive from voting. The theory is not categorical about whether voters' interest is immediate of futuristic. That is, whether they will gain immediate gratification or fulfillments that will come when a government is formed. However, it has established that voters are rational, and even when persuaded by politicians and their parties, they react or respond based on their interests and envisaged gains. It means that voters are active participants in electoral processes.

The two theories are, therefore, relevant to this study. There is an interface between the theories. While the sociological theory posits that voters behaviour is dependent on groups to which they belong as well as their personality rather than too much influence from exposure to the media, the Rational Choice theory talks about voters' interest and benefits which are pursued rationally. The link is that the group has a common goal to pursue 
and protect. Individuals also have interests to protect. So, anything outside the group's and individuals' interests will not be rationally pursued, irrespective of persuasion and media messages.

\section{Review of Literature:- Conceptual review:}

Politics is conceived in a different perspective and has been conceptualized by many including Heywood (2007) who defined politics as the exercise of control within the society through the making and enforcement of collective decisions (p.5). This definition finds relevance in the submission by Appadorai (1974) who explains the essence of politics thus:

...everyone cannot have his way, because he lives in society. One man's desires conflict with those of another. The relations of the individual members of the society with one another, therefore, need regulation by government. When a body of people is clearly organized as a unit for purposes of government, then it is said to be politically organized and may be called a body politic or state-a society politically organized (p.3).

Politics is a known phenomenon the world over, and the term has been used in many kinds of literature including those of mass communication. So, whether used as a noun or as an adjective, it seeks to properly address the issue under consideration to give it the meaning it deserves when subjected to the wider meaning of 'politics'. In Mass Communication, there is a form of communication referred to as political advertising and/or political communication, which Odoakah (1998) views as a big business in a political system. It is an investment. Both government and political parties trade on political information. Political communication, therefore, can be said to be a process whereby political information is passed on to whom it may concern by those assigned or who such responsibility...The channels of political communication include those of organizational communication and the media of mass information (p.3). Udoakahgoes on to quoteWindlesham to have conceptualized political communication asthe deliberate passing of a political message by a sender to a receiver to make the receiver behave in a way that he might not otherwise have done. This definition contains three components: a political message; a method of passing or distributing the political message; and an intention to make the receiver respond in a particular way (p.4). From these definitions, we can say that political communication can be viewed as political advertising, depending on how the information is packaged and disseminated. It is political communication when the message is framed by politicians, their spokespersons or party's spokesmen and disseminated in the media or through other modes of communication without directly seeking or asking for a vote but to draw people to the party. It becomes political advertising when the information or message directly solicits votes from the electorate while promoting a candidate or candidates of a political party over others. Therefore, political advertising is a form of message in the media that is sponsored by identified persons or groups, which seeks to promote the candidacy of a person and a political party above others ahead of the election to secure more votes than other parties. It is persuasive in nature, and it is usually entertaining. It is a part of the entire electioneering process or campaign. This is why Agba (2006) notes that electioneering campaigns are media events. They encapsulate all that political parties have to show for the suitability of their candidates and the genuineness of their party...The mass media are a pivot of social interaction (p.193).

\section{Empirical Review:}

There is a growing number of studies in political advertising and voters' behaviour in academic literature due to theperceived influence of political advertising on voters' behaviour.

Udeze and Akpan (2013) examined the influence of political advertising on the choice of governorship candidates in Imo State during the 2011 governorship election. The study showed that the majority of the electorate in the State were exposed to political advertising, mainly onthe radio which to a large extent influenced the choice of candidates during the governorship election.

Another study was conducted by Ezegwu (2015), which examined the extent the electorate in Aguata Local Government Area of Anambra State wasexposed to political advertising. The study showed that voters were influenced by political advertising which reflected in their choice of candidates during the 2015 general elections. The outcome of the study also revealed that the electorate was exposed to political advertising but mainly on radio, which was the major medium of political advertising in the LGA. 
On their part, Tejumaiye, Simon and Obia(2018) examined the role of political advertising in the 2015 Presidential Election in Lagos State. They discovered that most of the respondents were influenced by political advertising in their choice of voting for a political party during the 2015 presidential poll. They further identified factors such as ethnic considerations, religious beliefs and other factors to have influenced their voting pattern.

Sule,Sani and Mat(2017) in their study examinedthe extent to which the 2015 Presidential Election differs from the previous Presidential Elections inNigeria. The study revealed that the 2015 Presidential Election was different to some extent with the previous presidential Polls in Nigeria in term of voters' influence. The influence was attributed to factors such as religious affiliation, ethnicity, regionalism, nepotism, issue-based politicsincluding corruption, insecurity, poverty, unemployment, among others which influenced the politicalbehaviour of the electorate.

Kachii,(2018) assessed the impact of political advertising onthe voting behaviour ofthe electoratein Benue State. Specifically, the study was conducted to unravel the influence of politically motivated campaign songsduring the 2015 elections on the electorate in Benue State.The study revealed that campaign songs only created the political atmosphere and promoted political candidates but did not guarantee electoral victory.On his part, Ojekwe(2016) examined the effectiveness of political campaigns in shaping the voting behaviourof Nigerian voters in Lagos state.The study focused on the AllProgressive Congress governorship candidate in Lagos State, AkinwunmiAmbode, and revealed that political advertising did not havea strong effect on the electorate's voting behaviour.

The above are all studies on political advertising and voters' behaviour in different parts of Nigeria. None of them investigates the situation in Lokoja, Kogi State capital or Kogi State in general. There is, therefore, a gap in the literature concerning political advertising and voters' behaviour in Lokoja, which this study seeks to fill.

\section{Methodology:-}

The survey design was adopted for this study. This is because the study deals with opinions, attitudes and characteristics of people. Ohaja (2003) says the survey is usually employed in studies of attitudinal and behavioural trends with the researcher seeking to uncover their demographic or psychographic underpinnings (p.11).

The population of Lokoja, Kogi State capital, according to 2006 census figure is 195, 261, while according to Nigeria Civil Society Situation Room for Kogi State Governorship Election, 2019, retrieved from www.placng.org on January 12, 2020,Lokoja has 137.301 registered voters but 118, 673 has Permanent Voters' Cards. 83

A sample size of 400 was used for the study after Taro Yamane's formula was used in calculating what would be the appropriate sample size considering the number of voters with Permanent Voters Card.

Probability sampling technique, specifically, stratified random sampling was adopted for the study. Stratified random sampling was considered "because it assures for more representation of every segment of the population" (Ihejirika and Omego, 2013, p. 108). So, in distributing the questionnaire, Lokoja was segmented into 10 areas: Felele, Old Market, Adankolo, Lokogoma phase 1, Lokogoma phase 2, Kabawa, Gadumu, New layout, Peace Community and Ganaja. Forty pieces of the questionnaire were administered on respondents in each of the areas segmented

The data was analyzed using simple frequency distribution tables, percentages, weighted mean scores (wms) from Likert-type questions. In analyzing data from the five-point scale Likert-type question in the instrument, responses to items will be shown as follows:

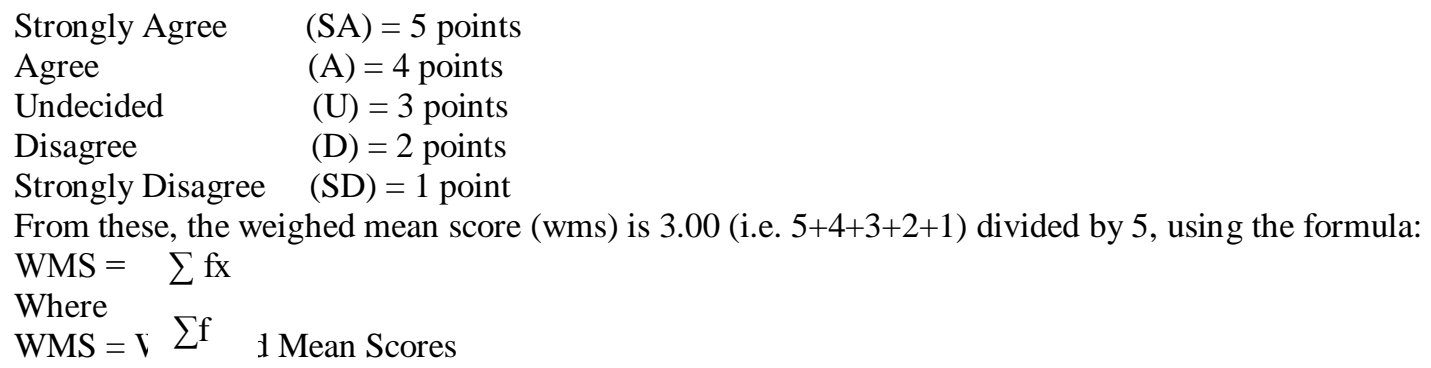


$\sum \mathrm{fx}=$ Summation of frequency $\mathrm{x}$ score and

$\sum \mathrm{f}=$ Summation of frequencies

Presentation of Data:

Table 1:- Shows the Social Characteristics of Respondents.

\begin{tabular}{|l|l|l|}
\hline Gender & Number of Respondents & Percentage \\
\hline Male & 228 & 59.4 \\
\hline Female & 156 & 40.6 \\
\hline Total & 384 & 100 \\
\hline Educational Qualifications & & \\
\hline SSCE & 64 & 16.7 \\
\hline OND & 88 & 22.9 \\
\hline HND & 96 & 25 \\
\hline B.Sc. & 108 & 28.1 \\
\hline M.Sc. & 24 & 6.3 \\
\hline PhD. & 4 & 1 \\
\hline Total & 384 & 100 \\
\hline Marital Status & & \\
\hline Single & 112 & 29.2 \\
\hline Married & 256 & 66.7 \\
\hline Widow & 12 & 3.1 \\
\hline Widower & 4 & 1 \\
\hline Total & 384 & 100 \\
\hline
\end{tabular}

Source: Survey 2020

\section{Psychographic Data Presentation:}

I voted the candidate because of the electioneering campaign on radio, television, billboards and in the social media

\begin{tabular}{|l|l|l|l|l|l|}
\hline $\begin{array}{l}\text { Strongly } \\
\text { Agree }\end{array}$ & 110 & 5 & 550 & & \\
\hline Agree & 92 & 4 & 368 & & \\
\hline Undecided & 10 & 3 & 30 & & \\
\hline Disagree & 134 & 2 & 268 & & \\
\hline $\begin{array}{l}\text { Strongly } \\
\text { Disgrace }\end{array}$ & 38 & 1 & 38 & & \\
\hline Total & 384 & 15 & 1254 & 3.2 & Decision: Accepted \\
\hline
\end{tabular}

I know more about the candidate because of the campaign on radio, television, billboards and in the social media

\begin{tabular}{|l|l|l|l|l|l|}
\hline $\begin{array}{l}\text { Strongly } \\
\text { Agree }\end{array}$ & 72 & 5 & 360 & & \\
\hline Agree & 124 & 4 & 496 & & \\
\hline Undecided & 38 & 3 & 114 & & \\
\hline Disagree & 68 & 2 & 136 & & \\
\hline $\begin{array}{l}\text { Strongly } \\
\text { Disgrace }\end{array}$ & 82 & 1 & 82 & & \\
\hline Total & 384 & 15 & 1188 & 3.09 & Decision: Accepted \\
\hline
\end{tabular}

I was convinced to participate in the election due to campaign on radio, television, billboards and in the social media

\begin{tabular}{|l|l|l|l|l|l|}
\hline $\begin{array}{l}\text { Strongly } \\
\text { Agree }\end{array}$ & 88 & 5 & 440 & & \\
\hline Agree & 88 & 4 & 352 & & \\
\hline
\end{tabular}




\begin{tabular}{|c|c|c|c|c|c|}
\hline Undecided & 40 & 3 & 120 & & \\
\hline Disagree & 80 & 2 & 160 & & \\
\hline $\begin{array}{l}\text { Strongly } \\
\text { Disgrace }\end{array}$ & 88 & 1 & 88 & & \\
\hline Total & 384 & 15 & 1160 & 3.02 & Decision: Accepted \\
\hline \multicolumn{6}{|c|}{$\begin{array}{l}\text { I voted the candidate because of the consistent campaignon radio, television, billboards and in the social } \\
\text { media }\end{array}$} \\
\hline $\begin{array}{l}\text { Strongly } \\
\text { Agree }\end{array}$ & 75 & 5 & 375 & & \\
\hline Agree & 82 & 4 & 328 & & \\
\hline Undecided & 51 & 3 & 153 & & \\
\hline Disagree & 86 & 2 & 172 & & \\
\hline $\begin{array}{l}\text { Strongly } \\
\text { Disgrace }\end{array}$ & 90 & 1 & 90 & & \\
\hline Total & 384 & 15 & 1118 & 2.9 & Decision: Rejected \\
\hline \multicolumn{6}{|c|}{$\begin{array}{l}\text { The campaign by the Political partieson radio, television, billboards and in the social media made me change } \\
\text { my mind concerning a particular candidate and eventually voted the candidate I would not have voted }\end{array}$} \\
\hline $\begin{array}{l}\text { Strongly } \\
\text { Agree }\end{array}$ & 44 & 5 & 220 & & \\
\hline Agree & 48 & 4 & 192 & & \\
\hline Undecided & 28 & 3 & 84 & & \\
\hline Disagree & 100 & 2 & 200 & & \\
\hline $\begin{array}{l}\text { Strongly } \\
\text { Disgrace }\end{array}$ & 164 & 1 & 164 & & \\
\hline Total & 384 & 15 & 860 & \begin{tabular}{l|l|} 
& 2.23 \\
\end{tabular} & Decision: Rejected \\
\hline \multicolumn{6}{|c|}{ I voted the candidate because he (she) is from my ethnic group } \\
\hline $\begin{array}{l}\text { Strongly } \\
\text { Agree }\end{array}$ & 44 & 5 & 220 & & \\
\hline Agree & 36 & 4 & 144 & & \\
\hline Undecided & 20 & 3 & 60 & & \\
\hline Disagree & 92 & 2 & 184 & & \\
\hline $\begin{array}{l}\text { Strongly } \\
\text { Disgrace }\end{array}$ & 192 & 1 & 192 & & \\
\hline Total & 384 & 15 & 436 & 1.14 & Decision: Rejected \\
\hline \multicolumn{6}{|c|}{ I voted the candidate because members of my group agreed that he (she) should be voted } \\
\hline $\begin{array}{l}\text { Strongly } \\
\text { Agree }\end{array}$ & 40 & 5 & 200 & & \\
\hline Agree & 52 & 4 & 208 & & \\
\hline Undecided & 44 & 3 & 132 & & \\
\hline Disagree & 140 & 2 & 280 & & \\
\hline $\begin{array}{l}\text { Strongly } \\
\text { Disgrace }\end{array}$ & 108 & 1 & 108 & & \\
\hline Total & 384 & 15 & 928 & 2.41 & Decision: Rejected \\
\hline \multicolumn{6}{|c|}{ I voted the candidate because I was given money } \\
\hline $\begin{array}{l}\text { Strongly } \\
\text { Agree }\end{array}$ & 20 & 5 & 100 & & \\
\hline Agree & 27 & 4 & 48 & & \\
\hline Undecided & 10 & 3 & 30 & & \\
\hline Disagree & 161 & 2 & 322 & & \\
\hline $\begin{array}{l}\text { Strongly } \\
\text { Disgrace }\end{array}$ & 166 & 1 & 166 & & \\
\hline
\end{tabular}




\begin{tabular}{|c|c|c|c|c|c|}
\hline Total & 384 & 15 & 666 & 1.73 & \begin{tabular}{l|l} 
& Decision: Rejected \\
\end{tabular} \\
\hline \multicolumn{6}{|c|}{ I voted the candidate because I was intimidated by political thugs } \\
\hline $\begin{array}{l}\text { Strongly } \\
\text { Agree }\end{array}$ & 16 & 5 & 80 & & \\
\hline Agree & 21 & 4 & 84 & & \\
\hline Undecided & 40 & 3 & 120 & & \\
\hline Disagree & 119 & 2 & 238 & & \\
\hline $\begin{array}{l}\text { Strongly } \\
\text { Disgrace }\end{array}$ & 188 & 1 & 188 & & \\
\hline Total & 384 & 15 & 710 & 1.8 & Decision: Rejected \\
\hline \multicolumn{6}{|c|}{ I voted the candidate because naturally, I like him/her } \\
\hline $\begin{array}{l}\text { Strongly } \\
\text { Agree }\end{array}$ & 161 & 5 & 805 & & \\
\hline Agree & 80 & 4 & 320 & & \\
\hline Undecided & 27 & 3 & 81 & & \\
\hline Disagree & 64 & 2 & 128 & & \\
\hline $\begin{array}{l}\text { Strongly } \\
\text { Disgrace }\end{array}$ & 52 & 1 & 52 & & \\
\hline Total & 384 & 15 & 1386 & 3.60 & Decision: Accepted \\
\hline \multicolumn{6}{|c|}{ I voted the candidate because he/she is a member of my party } \\
\hline $\begin{array}{l}\text { Strongly } \\
\text { Agree }\end{array}$ & 96 & 5 & 480 & & \\
\hline Agree & 84 & 4 & 336 & & \\
\hline Undecided & 12 & 3 & 36 & & \\
\hline Disagree & 85 & 2 & 170 & & \\
\hline $\begin{array}{l}\text { Strongly } \\
\text { Disgrace }\end{array}$ & 107 & 1 & 107 & & \\
\hline Total & 384 & 15 & 649 & 1.69 & Decision: Rejected \\
\hline \multicolumn{6}{|c|}{ I voted the candidate because I was promised a better Job } \\
\hline $\begin{array}{l}\text { Strongly } \\
\text { Agree }\end{array}$ & 64 & 5 & 320 & & \\
\hline Agree & 36 & 4 & 144 & & \\
\hline Undecided & 22 & 3 & 66 & & \\
\hline Disagree & 110 & 2 & 220 & & \\
\hline $\begin{array}{l}\text { Strongly } \\
\text { Disgrace }\end{array}$ & 152 & 1 & 152 & & \\
\hline Total & 384 & 15 & 902 & 2.34 & Decision: Rejected \\
\hline
\end{tabular}

Source: Survey 2020

Discussion of findings:

From the above analysis 110 of the respondents strongly agreed while 92 respondents agreed that they voted the candidate of their choice because of electioneering campaign on radio, television, billboards and in the social media. Meanwhile, 8 of the respondents were undecided. Also, 134 and 38 of the respondents disagreed and strongly disagreed correspondingly that they voted the candidate of their choice because of the electioneering campaign on radio, television, billboards and in the social media. Also, 72 and 124 of the respondents strongly agreed and agreed that they knew more about the candidates they voted for because of the campaign on radio, television, billboards and in the social media, while, 38 of the respondents were undecided. Moreover, 68 and 84 of the respondents disagreed and strongly disagreed that they knew more about the candidates they voted for because of the campaign on radio, television, billboards and in the social media.Furthermore, 88 and 88 of the respondents strongly agreed and agreed that they were convinced to participate in the election due to the electioneering campaign on radio, television, billboards and in the social media, while, 40 of the respondents were undecided. However, 80 of the respondents 
disagreed and 88 of the respondents strongly disagreed that they were convincedto participate in the election due to the electioneering campaign on radio, television, billboards and in the social media.

However, 75 of the respondents strongly agreed and 82 of the respondents agreed that they voted for the candidate of their choice because of the consistent campaign on radio, television, billboards and in the social media, while, 51 of the respondents were undecided. Nevertheless, 86 and 90 of the respondents disagreed and strongly disagreed that they voted the candidate of their choice because of the consistent campaign on radio, television, billboards and in the social media. From the above analysis, therefore, items 1, 2, 3 and 4 on the questionnaire have answered research objective one which is "To ascertain the exposure of electorate in Lokoja to political advertising during 2019 governorship poll in Kogi State". It means that the electorate was exposed to political advertising on radio, television, billboards and in the social media, and knew more about the candidates they voted for due to campaign on and in those media. They were also convinced to cast their vote due to the campaign. However, the electioneering campaigns were not sustained. In the meantime, the study revealed that 44 and 48 of the respondents strongly agreed and agreed that electioneering campaign by the various political parties on radio, television, billboards and in the social media made them change their mind regarding the candidate they voted for in the 2019 gubernatorial election in Kogi State. Besides, 28 of the respondents were undecided, while, 100 and 164 of the respondents disagreed and strongly disagreed. It means that the electioneering campaigns on and in the various media did not influence most of the respondents to change their minds concerning candidates of their choice. Therefore, item 5 on the questionnaire has answered research question 2 which is to "Determine if the political advertising influence voters' behaviour".

Also, the study revealed that 44 and 36 of the respondents strongly agreed and agreed that they voted the candidate of their choice because they are from the same ethnic group, while 20 of the respondents were undecided. Besides, 92 and 192 of the respondents disagreed and strongly disagreed that they voted the candidate of their choice because they are from the same ethnic group.The study equally shows that 40 and 52 of the respondents strongly agreed and agreed that they voted the candidate of their choice because members of their social group agreed that they should vote for such candidate, while 44 of the respondents were undecided. Also, 140 and 108 of the respondents disagreed and strongly disagreed that they voted the candidate of their choice because members of their social group agreed that they should vote for such candidate.

Also, 20 and 27 of the respondents strongly agreed and agreed that they voted candidates of their choice because they were given money, while, 10 of the respondents were undecided. More so, 161 and 166 of the respondents disagreed and strongly disagreed that they voted candidates of their choice because they were given money. Furthermore, 16 and 21 of the respondents strongly agreed and agreed that they voted the candidate of their choice because they were intimidated by political thugs. Also, 40 of the respondents were undecided, while, 119 and 188 of the respondents disagreed and strongly disagreed that they voted the candidate of their choice because they were intimidated by political thugs.

The study shows that 161 and 80 of the respondents strongly agreed and agreed that they voted the candidate of their choice because they naturally like them. Also, 27 of the respondents were undecided, while, 64 and 52 of the respondents disagreed and strongly disagreed that they voted the candidate of their choice because they naturally like them. More so, 96 and 84 of the respondents strongly agreed and agreed that they voted the candidates of their choice because they are members of their party, while 12 of the respondents were undecided. Also, 84 and 107 of the respondents disagreed and strongly disagreed that they voted the candidates of their choice because they are members of their party.

Lastly, 64 and 36 of the respondents strongly agreed and agreed that they voted the candidate of their choice because they were promised a better job, while 22 of the respondents were undecided. Besides, 110 and 152 of the respondents disagreed and strongly disagreed that they voted the candidate of their choice because they were promised a better job. Items 6-12 as contained on the questionnaire were used in the data analyses as contained in table 6-12. These items have, therefore, answered research question 3 which is "What factors sway voting behaviour of the electorate in Lokoja during 2019 Governorship election? Deductively, therefore, the electorate voted the candidates of their choice because they naturally liked them.

\section{Summary/ Conclusion:-}

The study was undertaken to ascertain political advertising and voters' behaviour in Lokoja during the 2019 governorship poll in Kogi State. The study sought to achieve three objectives and asked three research questions. 
Also, two theories (Sociological and Rational Choice Theories), were adopted for this study. The sociological theory maintains that voters or electorate remain rooted in the group's interest and reflections, rather than having feelings for a political party due to family influence. The theory stressed that the media have a limited effect on the voting decision but noted that social group and personality of the individual voters determine their voting behaviour. On the other hand, Rational Choice Theory holds that voters' behaviour and decision are based on interest and the utility (benefits) to derive from voting. The theory is not categorical about whether voters' interest is immediate of futuristic. That is, whether they will gain immediate gratification or fulfillments that will come when a government is formed. However, it has established that voters are rational, and even when persuaded by politicians and their parties, they react or respond based on their interests and envisaged gains. It means that voters are active participants in electoral processes.

The study has confirmed the two theories that the researchers adopted for it. From the discussion of findings, it is clear that the electorate made a rational choice. The choice is also tied to their envisaged gains. Therefore, even when groups' interests are noted, only the group's economic pursuit which re-enforces the individual voters' economic interests isadhered to. As noted by Heywood (2007), ' '. . electors tend to adopt a voting pattern that reflects the economic and social position of the group to which they belong". This group could be religious, class, gender, ethnicity, religion, region. Meanwhile, in all of these, the personality of the individual voters matters a lot. This explains why the electorate voted the candidates of their choice because they naturally liked them; not because they were given money, intimidated, from their ethnic group, from the same political party, promised a better job or because as members of a group they were told to vote a particular candidate. However, the Rational Choice Theory is made more manifest in this study than the Sociological theory. The basic thing, therefore, is interest and envisaged economic and other gratification that ring bell on the minds of the electorate. It also means that electorate's level of education is a factor to be considered when discussing the two theories because only those that are educated conventionally would make a rational choice and weigh group's position to ascertain the economic variable, among others. As could be seen from the social characteristics of the respondents, 28.1 per cent of the voters are educated up to the university level, and this percentage is the highest among the categories of the electorate's academic qualification.

Deductively, therefore, we can conclude that political advertising played little role in the voting behaviour of the electorate in Lokoja during the 2019 governorship poll in Kogi State. The electorate exposed themselves to the media knew more about the candidates through political advertising and were convinced to participate in the election as a result of political advertising. But the hype such political persuasion did not rule out their interests and envisaged gains which made them make rational choices. In categorical submission, we conclude that political advertising on and in the various mass media had little effect on voters' behaviour in Lokoja during the 2019 governorship poll.Given this, the hypothesis which holds that there is a significant relationship between political advertising on radio, television, billboards and in the social media and voters' choice ofa candidate during polls is rejected. Meanwhile, based on the problem which prompted this study and the subsequent findings, it has opened up other areas of research like the credibility of the 2019 governorship polls in Kogi State, which we believed researchers will be interested in researching this area.

\section{Recommendations:-}

The following recommendations are made:

1. Political advertising should be sustained in and on any chosen mass media by political parties. This could greatly influence voters' behaviour in Lokoja during subsequent elections.

2. Interpersonal communication and trado-modern political advertising should be adopted to complement the effects of the mass media on the electorate.

3. Politicians should have a charismatic disposition that will position them on the minds of the electorate, and should not depend largely on political advertising for acceptance by the electorate.

4. Politicians should have a long-standing view on issues they bring out as their Unique Selling Points during the election. This will enable the electorate to believe in their submissions during campaigns.

\section{References:-}

1. Agba, P.C (2006). Mass media and electioneering campaign reporting: the contemporary dimension. In Okoro (Ed).International journal of communication an interdisciplinary journal of communication studies (5), 199-205

2. Appadorai, A. (1974). The substance of politics. New Delhi: OUP Higher Education Division 
3. Ezegwu, D. (2015).Political advertising and the electorate's choice of candidates in Nigeria's 2015general election: A study of select electorate in Anambra State Communication Panorama African and Global Perspectives Vol. 1 (1), 1-16

4. Heywood, A. (2007). Politics third edition. New York: Palgrave Macmillan.

5. Ihejirika, W.C \&Omego, C. (2013) Research methods in linguistics and communication studies (second impression). Choba: University of Port Harcourt Press Ltd.

6. Kachii, V. (2018). Politically motivated campaign songs and voting behaviour: Reflections on Tiv campaign songs in the 2015 elections in Benue state Africology: The Journal of Pan African Studies, Vol.12 (6), 205-2014

7. Ohaja, E.U (2003).Mass communication research and project report writing. Lagos: John Letterman Ltd.

8. Ojekwe, I.G. (2016). Political advert campaigns and voting behaviour: AkinwunmiAmbode's 2015 Election Campaign in Lagos State Journal of African ElectionsDOI: 10.20940/JAE/2016/v15i2a 1

9. Rui A. (2010). Theoretical models of voting behaviour https://www.researchgate.net/publication/242653736 retrieved on November 30, 2019

10. Sule,B., Sani,M.A.M \& Mat, B. (2017).Political behaviour and voting pattern in Nigeria: A study of 2015 presidential election. Asia Pacific Journal of Education, Arts and Sciences, Vol. 4 (4), 1-13

11. Tejumaiye, J.A, Simon, G.I, \&Obia, V.A. (2018). Political advertising in Nigeria's 2015 presidential election. Global media journal Vol. 16 (31) 122 1-11.

12. Udeze, S.\&Akpan, U. (2013). The influence of political advertising on Nigerian electorate. Journal of Communication, 4(1): 49-55.

13. Udoakah, N. (1998). Development communication. Ibadan: Stirling-Horden Publishers. 